\title{
Edible coating in the post-harvest conservation of endemic mangaba
}

\section{Recubrimiento comestible en la conservación poscosecha del mangaba endémico}

ANA PAULA SILVA SIOUEIRA' 1,3

MARIA EDUARDA IACHINSKI MELO'

FELIPE DE OLIVEIRA BONIFÁCIO' ${ }^{1}$

LEONARDO JOSÉ URZÊDA NUNES DE MELO'

LUCAS SILVA TIZZO'

ELI REGINA BARBOSA DE SOUZA²

Fruit of Harconia speciosa.

Photo: A.P. Silva Siqueira

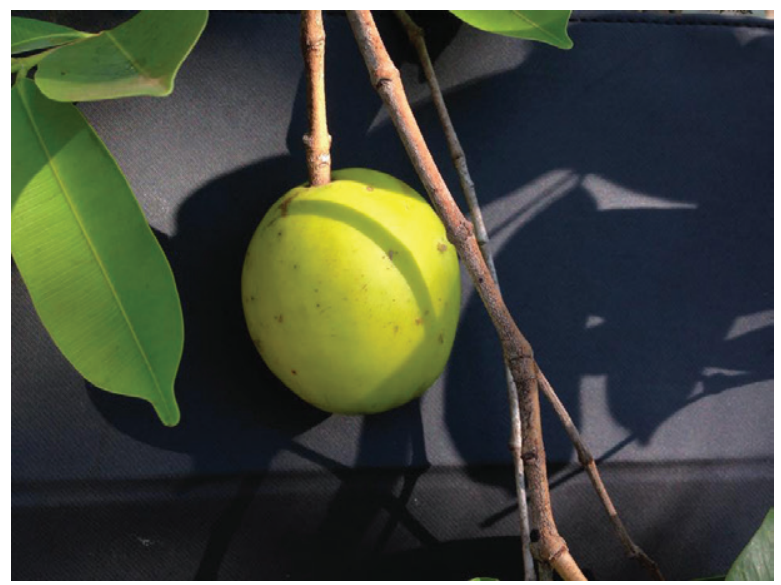

\begin{abstract}
Brazilian Cerrado is one of the largest biomes in the world and is considered the richest one. Mangaba fruit is representative of this biome, but it is highly perishable. The aim of this study was to evaluate the application of edible coatings on post-harvest mangaba. Fruits with a good appearance and absence of injuries were used. The experiment was done with a factorial scheme ( 3 treatments $\times 6$ storage periods). After sanitization and drying, the mangabas received the treatments: (1) whey protein coating; (2) corn starch coating; and (3) no coating (control). Trays with the fruits were stored at room temperature $\left(25^{\circ} \mathrm{C}\right)$. Mass loss, $\mathrm{pH}$, total soluble solids (TSS), total titratable acidity (TTA), firmness and ascorbic acid levels were evaluated after 0, 2, 4, 6, 8 , and 10 days of storage. The data were evaluated with analysis of variance, Tukey test and regression. The edible coating with whey protein obtained satisfactory results in the conservation of mangaba, showing good results for the TSS/TTA ratio (16) and vitamin C (116 mg/100 g). The coatings influenced the shelf-life and post-harvest characteristics of this fruits, but the coating with whey protein was the most indicated for mangaba.
\end{abstract}

Additional key words: covering, Harconia scpeciosa var. gardineri, cerrado, shelf-life.

\footnotetext{
1 Instituto Federal Goiano, Campus Morrinhos, Morrinhos-GO (Brazil). ORCID Silva Siqueira, A.P.: 0000-0003-32925836; ORCID Iachinski Melo, M.E.: 0000-0003-1024-5485; ORCID Bonifácio, F.d.O.: 0000-0001-9174-7107; ORCID Urzêda Nunes de Melo, L.J.: 0000-0002-8119-8113; ORCID Silva Tizzo, L.: 0000-0002-4512-8804

2 Universidade Federal de Goiás, Campus Samambaia, Goiânia-GO (Brazil). ORCID Barbosa De Souza, E.R.: 0000-00016225-6122

3 Corresponding author. ana.siqueira@ifgoiano.edu.br; siqueiracta@gmail.com
} 


\section{RESUMEN}

El Cerrado brasileño es uno de los mayores biomas del mundo y considerado el más rico. La fruta mangaba es representativa de este bioma pero es altamente perecedera. El objetivo de este estudio fue evaluar la aplicación de recubrimientos comestibles en la poscosecha de mangaba. Se utilizaron frutas con buen aspecto y ausencia de lesiones. El experimento se realizó en esquema factorial ( 3 tratamientos $\times 6$ períodos de almacenamiento). Después de la desinfección y secado, las mangabas recibieron los siguientes tratamientos: (1) recubrimiento de proteína de suero; (2) recubrimiento de almidón de maíz; (3) sin revestimiento (control). Las bandejas con los frutos se almacenaron a temperatura ambiente $\left(25^{\circ} \mathrm{C}\right)$. Se evaluaron los niveles de pérdida de masa, $\mathrm{pH}$, sólidos solubles totales (SST), acidez total titulable (ATT), firmeza y ácido ascórbico en periodos de almacenamiento de 0, 2, 4, 6, 8 y 10 días. Los datos fueron evaluados mediante análisis de varianza, prueba de Tukey y regresión. El revestimiento comestible con proteína de suero obtenido resultados satisfactorios en la conservación de mangaba, mostró buenos resultados para la relación SST/ATT (16) y vitamina C (116 mg/100 g). Los recubrimientos influyeron en la vida útil y en las características pos cosecha de estas frutas, pero el recubrimiento con proteína de suero de leche es el más indicado para la mangaba.

Palabras clave adicionales: cubierta, Harconia scpeciosa var. gardineri, cerrado, vida útil.

Received for publication: 30-03-2017 Accepted for publication: 30-09-2017
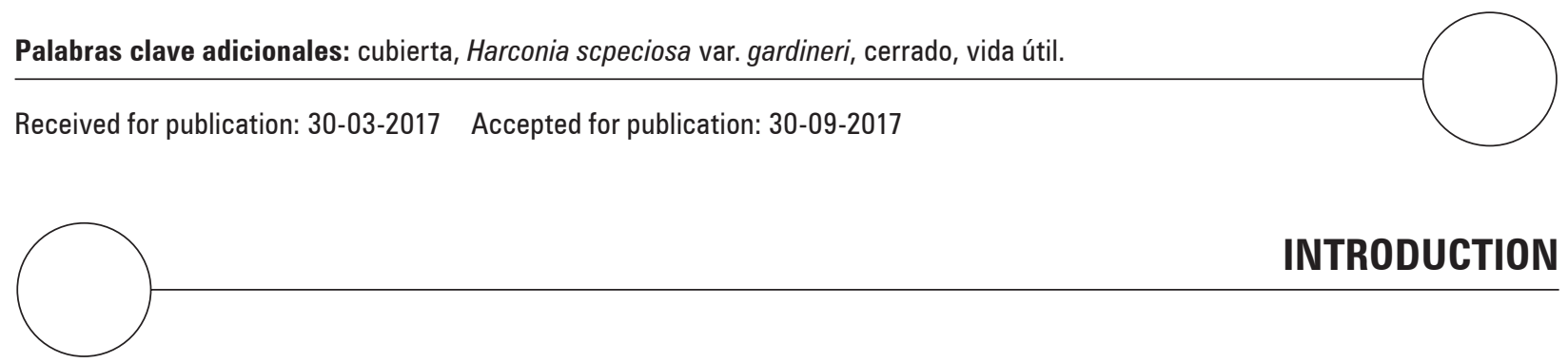

Brazilian Cerrado occurs predominantly in the central plateau of Brazil and occupies about $23 \%$ of the national territory (206 million of hectares). It is the second largest biome in Brazil, with a flora that is considered the richest among the savannahs of the world, with about 4,000 to 10,000 species of vascular plants (Aguiar et al., 2016).

Among the fruit species of Cerrado, there is mangaba (Hancornia speciosa), which is a fruit from the Apocynaceous family found in tropical climates, originally from Brazil; normally, vegetating and producing in latitudes from $20^{\circ}$ South (cold climate during the winter) to $10^{\circ}$ North (warm climate all year) Its wide dispersion in the territory proves its natural reproductive efficiency and the adaptability of the species to different environments (Vieira et al., 2010). The fruit has white, bittersweet and aromatic pulp, which can be consumed in natura or as jellies, ice cream, liqueur, candy, soda, wine or vinegar (Embrapa, 2007). However, it is highly perishable and susceptible to mechanical damage during harvesting, transport and handling, which represent a serious obstacle to commercialization (Campos et al., 2011).

The post-harvest quality of fruits is related to the minimization of the deterioration rate, that is, the maintenance of firmness, color, and appearance, aiming to keep them attractive to consumers for a longer period (Chitarra and Chitarra, 2005). In order to reach other markets, it is necessary to study new techniques of post-harvest conservation, which will maintain the quality of fruits for a longer period of time.

Thus, technologies can be applied in the post-harvest preservation of fruits, for example, edible coatings. These coatings inhibit or reduce the migration of moisture, oxygen, carbon dioxide, lipids, and aromas, as they promote semipermeable barriers, improving the physical integrity of the fruit (Vicentino et al., 2011). They are applied or formed directly on the surface of the fruits, forming thin membranes with several structural characteristics. The materials used in the formation of coatings should be considered GRAS (generally recognized as safe). Thus, they are non-toxic and safe for use in food (FDA, 2013). Several sensorial evaluations have been carried out, indicating the good acceptance of edible coatings or even the non-perception of their presence in food by judges. They can originate from different raw materials, such as proteinaceous, amylaceous or lipid matrices.

Therefore, the aim of this study was to apply edible coatings with whey protein and corn starch on mangaba fruits to evaluate the performance of this technology in increasing the shelf-life of the fruit. 


\section{MATERIALS AND METHODS}

The fruits were collected from the germplasm bank of the Federal University of Goiás at $16^{\circ} 35^{\prime} 12^{\prime \prime}$ South and $49^{\circ} 21^{\prime} 14^{\prime \prime}$ West, with an altitude of $730 \mathrm{~m}$. According to the classification by Köppen, the climate of the region is Aw (hot and semi-humid, with a dry season from May to September), with an average temperature of $22.3^{\circ} \mathrm{C}$. The soil is characterized as an Oxisol, with a medium and gently undulated texture. The average annual rainfall of the Cerrado Biome is $1,500 \mathrm{~mm}$, ranging from 750 to 2,000 mm (Adámoli et al., 1978).

About 200 Harconia speciosa var. gardneri fruits were harvested from different plants during the harvest of 2016. They were selected according to their appearance, absence of injuries and visual uniformity (size and green color, at physiological maturity). Then, they were washed with a neutral detergent and sanitized with $0.2 \mathrm{~g} \mathrm{~L}^{-1}$ of sodium hypochlorite. Subsequently, they were rinsed and exposed to room temperature drying and finally subjected to coating treatments and stored in open plastic trays.

The experiment was done with a factorial scheme $(3 \times 6)$ with three treatments: (T1) coating with whey protein, (T2) coating with corn starch, and (T3) no coating; and six storage periods $(0,2,4,6,8$ and $10 \mathrm{~d}$ after coating application) at $25^{\circ} \mathrm{C}$ in an air-conditioned room and three replications of five fruits per plot.

The coatings were prepared with two different formulations: with corn starch and with whey protein at a proportion of $4 \%$ in relation to the total formulation, along with $92 \%$ water, $2 \%$ glycerol (plasticizing agent) and $2 \%$ colorless gelatin to assist in the coating and fixation of the coating. The solutions were solubilized and heated at $90^{\circ} \mathrm{C}$ for $30 \mathrm{~min}$ in a water bath and cooled to reach $25^{\circ} \mathrm{C}$. The sanitized and dried mangabas were immersed in the solutions for $5 \mathrm{~min}$ and exposed on individual plastic trays so that the coating could drain and dry, the bottom of the trays was filled with a thin layer of the solution so that the lower part of the fruits was not uncovered.

The fruits were evaluated for firmness with the applanation technique (Calbo and Nery, 1995), calculating the pressure exerted by the glass plate on the fruit from the area of compression that could be visualized $(A=0.784 \times$ longer length $\times$ shorter length), the pressure being given by $\mathrm{F} / \mathrm{A}$, where $\mathrm{F}$ is the force exerted by the plate (from the plate weight) and the result expressed in Newton $(\mathrm{N})$. The ascorbic acid content was determined by expressing the equivalent in milligrams of ascorbic acid per $100 \mathrm{~g}$ of sample (Strohecker and Henning, 1976). To determine the mass loss, the fruits were weighed using an analytical balance. The total soluble solids (TSS), $\mathrm{pH}$, total titratable acidity (TTA) and ratio (TSS/TTA) were determined according to the methodologies described by the AOAC (2010). For the qualitative factors, the data were analyzed with analysis of variance and Tukey test, and, for the quantitative factors, regression analysis was used.

\section{RESULTS AND DISCUSSION}

When analyzing the coating factor, significance was observed for all variables (Tab. 1). The acidity was higher in the fruits without coating, and the soluble solids were higher for the treatment with starch. However, the ratio (TSS/TTA), important from an industrial point of view because it defines the balance between acidity and sweetness, was higher for the fruits with the protein coating.

Therefore, when evaluating the coating factor, the whey protein coating stood out because there was a hydrophobic relationship with the whey protein because of the temperature used $\left(90^{\circ} \mathrm{C}\right)$, which reduced the rate of fruit respiration, avoiding dehydration and alteration of the superficial appearance, reflected in the sensory characteristics (Assis and Brito, 2014).

The factor storage period was not significant, which resulted from the large variability in the maturation stage of the fruits from the beginning of the experiment (Tab. 1). This was because there is no standard for mangaba harvest and these fruits do not change color during maturation, but remain green.

Analyzing the interactions, it was noticed that, in general, most of the variables had significant interaction. For the total titratable acidity, there was little variation in the fruits with the protein coating, whereas, the control (without coating) presented a significant increase in acidity, a consequence of the activation of crop-induced glycolysis (Farias et al., 2011) (Fig. 1). The treatment with starch was interrupted on the $4^{\text {th }}$ day of evaluation because the fruits presented the development of microorganisms on the coating. This can be explained by the fact that amylaceous coverings are composed of sequences of simpler molecules and are attacked by microorganisms more. 
Table 1. Ratio (TSS/TTA), total titratable acidity (TTA), ascorbic acid (Vit. C), total soluble solids (TSS), pH and mass loss (ML) for mangabas submitted to the treatments: (1) whey protein coating, (2) amylaceous coating, and (3) without coating) in six evaluation periods and interactions between the factors.

\begin{tabular}{|c|c|c|c|c|c|c|c|}
\hline Coating & $\begin{array}{c}\text { Ratio } \\
\text { (TSS/TTA) }\end{array}$ & $\begin{array}{c}\text { TTA } \\
(\mathrm{g} / 100 \mathrm{~g}) \\
\end{array}$ & $\begin{array}{c}\text { Vit. C } \\
(\mathrm{mg} / 100 \mathrm{~g}) \\
\end{array}$ & $\begin{array}{c}\text { TSS } \\
\left({ }^{\circ} \text { Brix }\right) \\
\end{array}$ & $\mathrm{pH}$ & $\begin{array}{c}\text { Firmness } \\
\text { (N) }\end{array}$ & $\begin{array}{l}\text { ML } \\
(\%) \\
\end{array}$ \\
\hline 1 & $16.25 \mathrm{a}$ & $0.96 \mathrm{~b}$ & $116.65 \mathrm{a}$ & $13.71 b$ & $3.74 \mathrm{a}$ & $19.37 \mathrm{a}$ & $2.31 \mathrm{c}$ \\
\hline 2 & $9.45 c$ & $0.71 \mathrm{c}$ & $76.55 c$ & $16.38 \mathrm{a}$ & $2.42 b$ & $13.68 \mathrm{a}$ & $35.01 \mathrm{a}$ \\
\hline 3 & $13.69 \mathrm{~b}$ & $1.20 \mathrm{a}$ & $97.92 b$ & $10.94 \mathrm{c}$ & $3.86 \mathrm{a}$ & $18.85 \mathrm{a}$ & $8.61 \mathrm{~b}$ \\
\hline F1 & $32.94 * *$ & $22.38^{* *}$ & $17.66^{* *}$ & $63.10^{* *}$ & $90.23^{*}$ & $3.54^{*}$ & $195.56^{* *}$ \\
\hline \multicolumn{8}{|c|}{ Evaluation periods } \\
\hline 1 & 12.89 & 0.97 & 93.83 & 15.49 & 3.75 & 56.08 & 0.00 \\
\hline 2 & 13.61 & 1.13 & 118.96 & 9.67 & 3,61 & 36.66 & 2.00 \\
\hline 3 & 18.02 & 0.97 & 132.58 & 15.22 & 3.89 & 5.82 & 4.00 \\
\hline 4 & 14.16 & 1.16 & 98.32 & 15.27 & 3.84 & 2.63 & 8.00 \\
\hline 5 & 9.89 & 0.79 & 62.93 & 10.45 & 2.62 & 1.57 & 40.00 \\
\hline 6 & 10.21 & 0.73 & 75.62 & 15.95 & 2.33 & 1.04 & 42.00 \\
\hline F2 & 12.39 & 5.77 & 14.82 & 34.06 & 112.76 & 97.52 & 125.59 \\
\hline \multicolumn{8}{|c|}{ Interaction } \\
\hline $\mathrm{F} 1 \times \mathrm{F} 2$ & 9.50 & $8.75^{* *}$ & $8.52 * *$ & 37.27 & $90.23 * *$ & $3.91 * *$ & $105.68^{* *}$ \\
\hline
\end{tabular}

Means with different letters in the same column indicate significant differences according to the Tukey test $(P \leq 0.05) .{ }^{*}$ Significant at $1 \%$; ${ }^{*}$ Significant at $5 \%$.

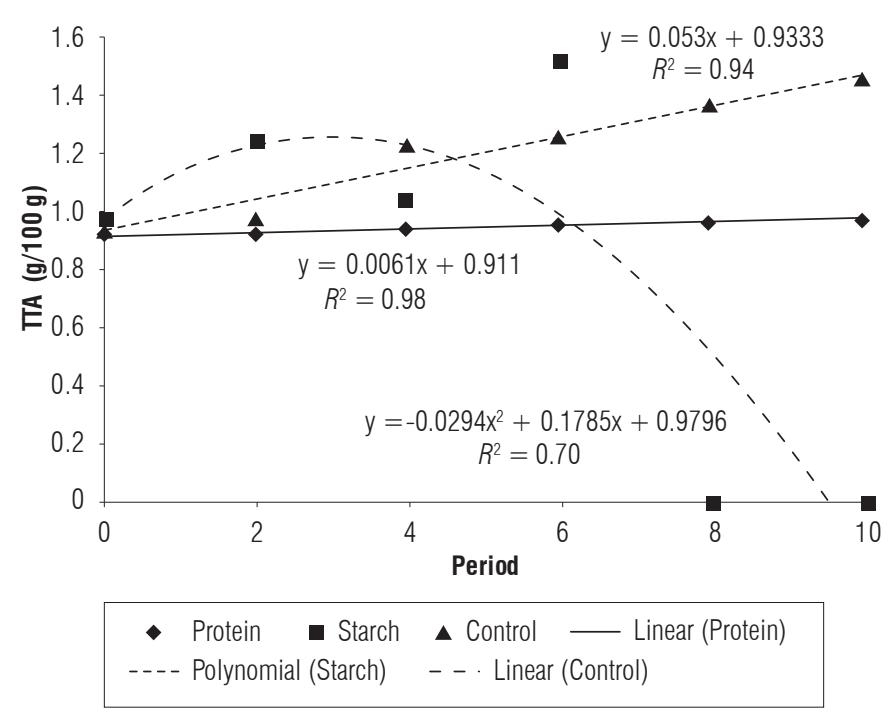

Figure 1. Interaction between the treatments and times for total titratable acidity (TTA).

Besides, it is a hydrophilic coating and generates a favorable environment for this type of event.

It was observed that, with time, the mangabas with the protein coating presented an increasing content of ascorbic acid (Fig. 2). Although the mangaba with starch presented an increase of ascorbic acid in the beginning of the experiment, it could not be verified over time because of the discarded fruit. Overall, the increase of ascorbic acid during ripening does not 
occur for all fruits and vegetables. In this case, this was a highlight in the preservation of the properties of the fruit, demonstrating an atypical case. This may have been caused by the advancement of oxidative reactions during ripening since ascorbic acid is a potential antioxidant in mangabas. However, it has been observed that some fruits and vegetables may present a retention or increase in vitamin $\mathrm{C}$ content during post-harvest storage; for example, asparagus presented an increase in ascorbic acid contents when stored at $4^{\circ} \mathrm{C}$ (Lee and Kader, 2000).

It was observed that the control matured more rapidly and suffered greater water loss because it had no barrier to the environment. It presented an increase in soluble solids because of a loss of water (Fig. 3) or

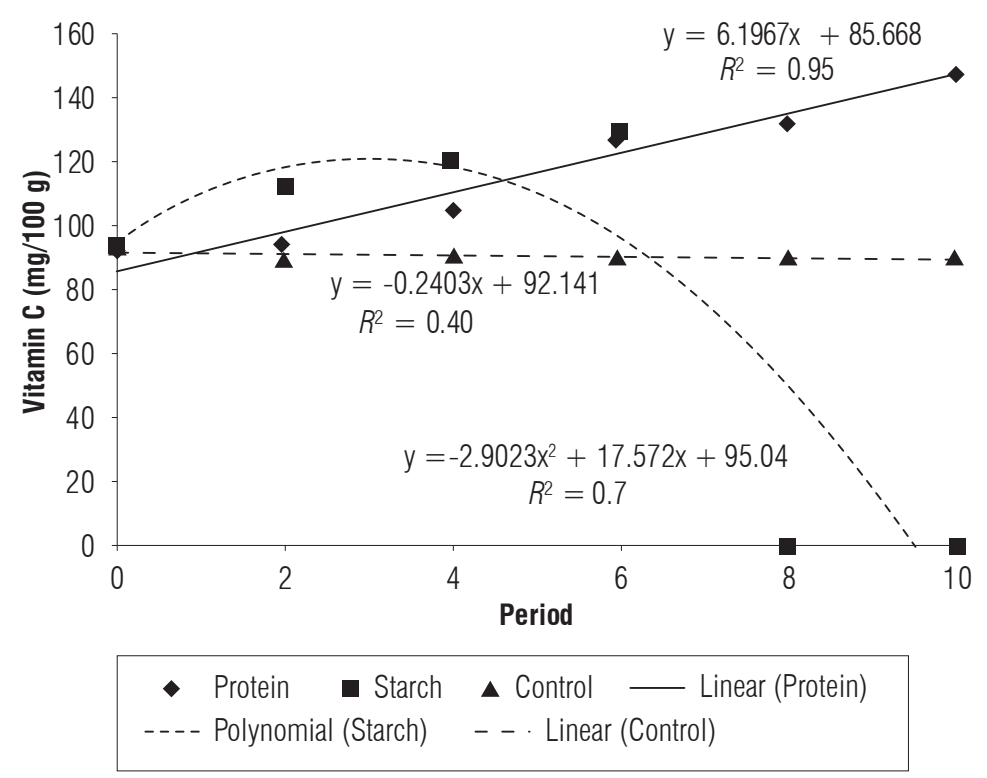

Figure 2. Interaction between treatments and times for vitamin C.

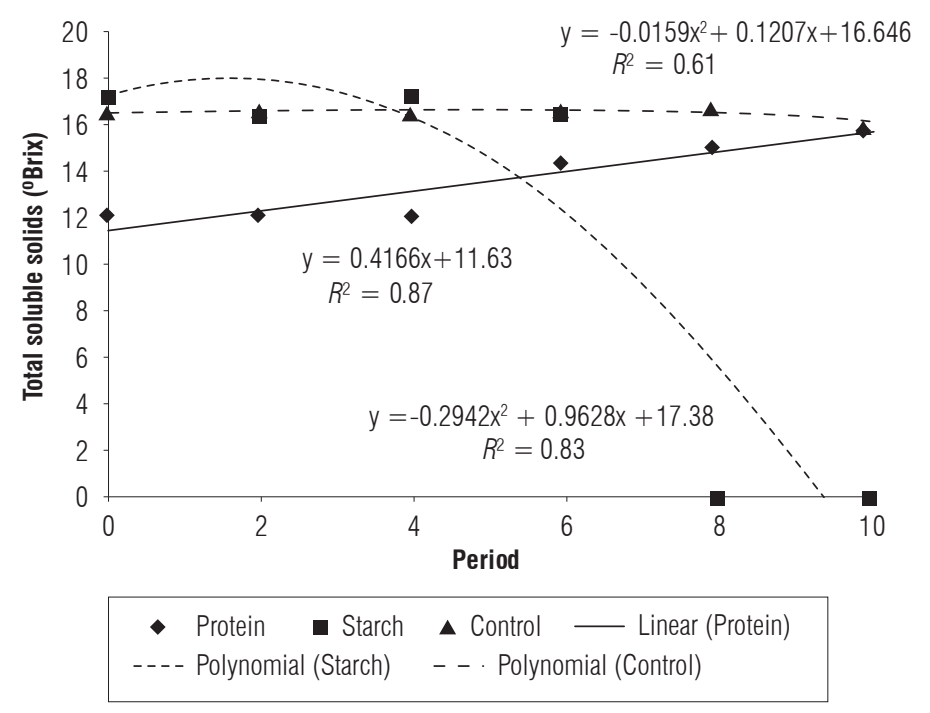

Figure 3. Interaction between treatments and times for total soluble solids ( ${ }^{\circ} \mathrm{Brix}$ ). 


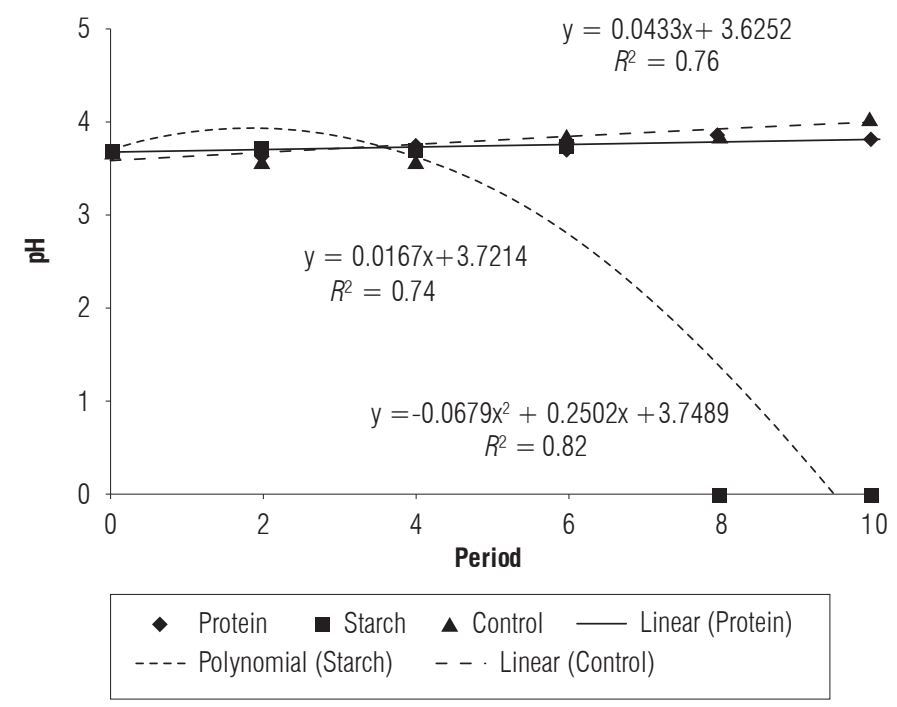

Figure 4. Interaction between treatments and times for $\mathrm{pH}$.

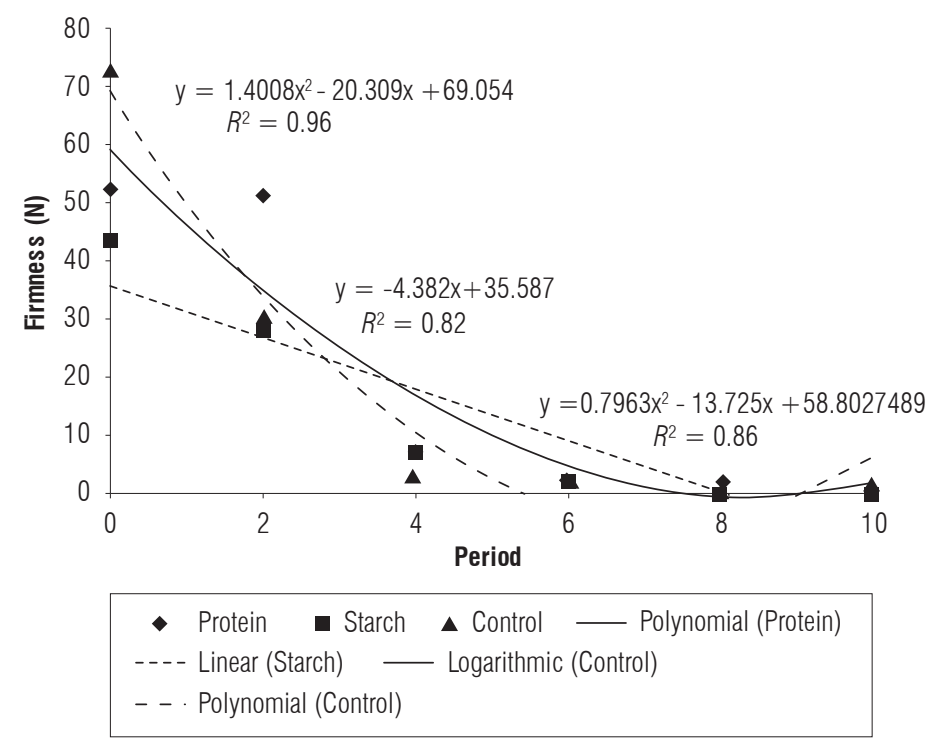

Figure 5. Interaction between treatments and times for firmness.

maturation that degrades more complex carbohydrates into simpler ones, increasing the solids content, which may also be seen in mangaba with a protein coating, although this increase in solids was more gradual. Initially, the mangaba with the starch coating had a higher soluble solids content, which may have been caused by the nature of the coating.
For $\mathrm{pH}$, the values were stable over time for the mangabas with a coating and for the control (Fig. 4). Initially, the behavior of the fruit with the starch coating was similar to the others. However, after losing the material, the final behavior could not be inferred. 


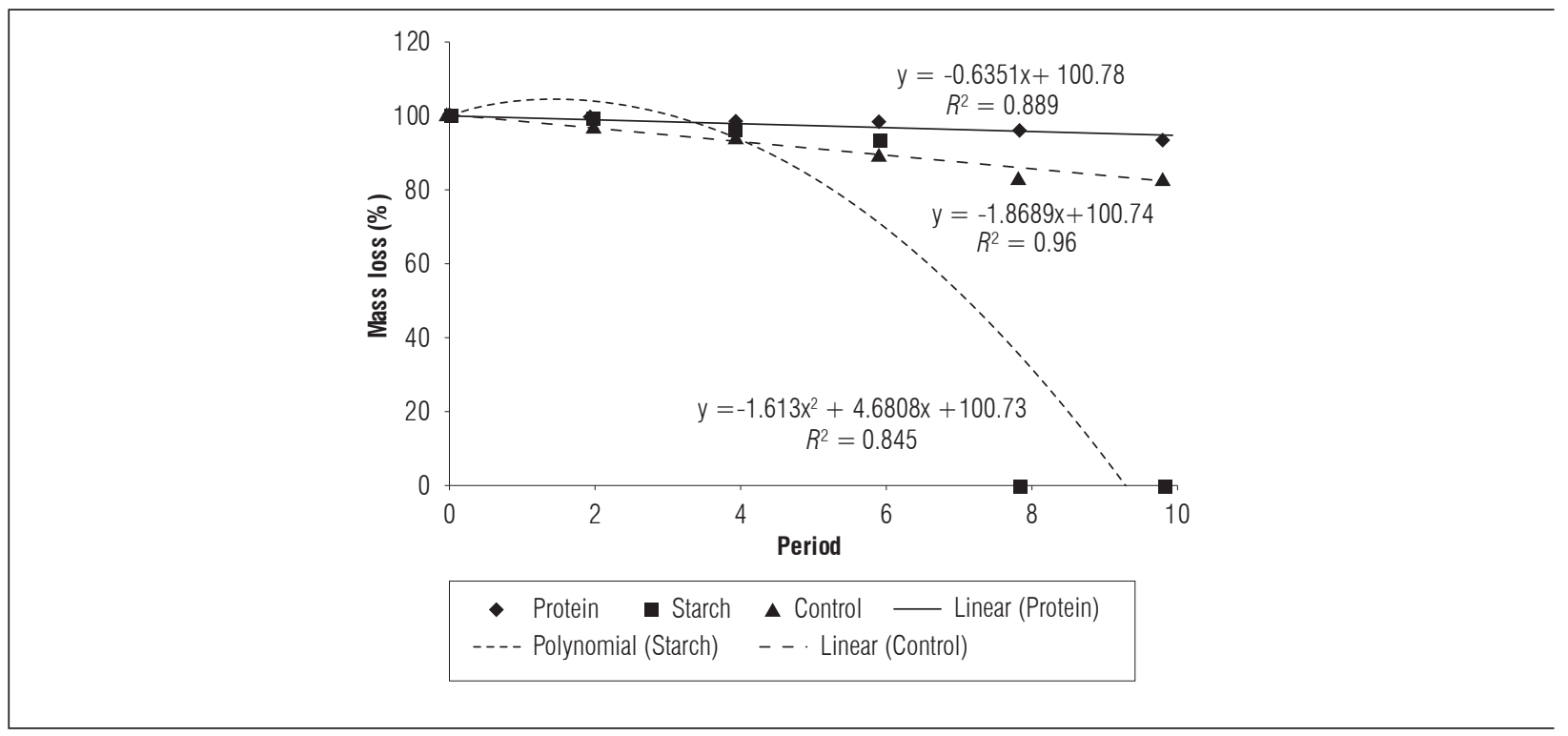

Figure 6. Interaction between treatments and times for mass loss.

The interaction between firmness and time demonstrated that the $4^{\text {th }}$ day was the intersection point for a considerable decrease in firmness (Fig. 5). However, the fastest drop of this attribute occurred in the mangabas without a coating since they had a greater loss in water content and also because these fruits matured faster than the others. Besides, during the maturation process, there is a solubilization of pectic substances, which promote the loss of firmness (Antunes et al., 2006).

The loss of mass was significant during the evaluation days and was higher for the control than for the mangabas with a coating. This was expected since the coatings are barriers to gas exchange and water loss (Fig. 6). The mangabas in the whey protein treatment showed a lower mass loss.

"Fallen" fruits are the most valued fruits on the market although they cannot be stored at room temperature and should be consumed quickly. Fruits that are harvested when unripe, as in the present study, do not present good quality for immediate consumption, but can be submitted to treatments that allow their controlled ripening, such as edible coatings and packages. In a study with "fallen" mangabas in the northeast region, the soluble solids content was $15 \%$, with $0.7 \mathrm{~g} / 100 \mathrm{~g}$ citric acid, $\mathrm{pH}$ of 3.5 and 274 $\mathrm{mg} / 100 \mathrm{~g}$ ascorbic acid (Carnelossi et al., 2004). In the present study, the ascorbic acid content was lower, which may be the result of the fruit variety and the different environmental conditions of the northeast and middle Cerrado.

In a study with the application of chitosan combined with the use of packages in mangabas from the northeast, it was observed that storage could be prolonged, with a reduction of mass loss until the sixth day of storage (Nasser et al., 2016). Whey proteins were also studied as an edible coating on apples and it was observed that there was no mass loss in relation to freshly harvested fruits (Gago et al., 2016). Researches with guava showed that the edible coatings caused an increase in fruit brightness, which pleased the consumers, leading to a greater acceptance of the overall appearance of the sample (Fakhouri and Grosso, 2013). Studies on protein coating on oranges showed that, in relation to the loss of fresh matter and physic-chemical changes of the fruits, the results had a small magnitude (Alleoni et al., 2006).

\section{CONCLUSIONS}

The coatings influenced the shelf-life and post-harvest characteristics of the fruits. The coating with whey protein showed a higher complexity of the material molecules, and it was observed that the fruits reached physiological maturation properly. With the whey protein coating, the fruits had better values for the ratio, vitamin $\mathrm{C}$, and firmness and had little weight loss. 
Conflict of interests: the manuscript was prepared and reviewed with the participation of the authors, who declare that there exists no conflict of interest that puts in risk the validity of the presented results.

\section{BIBLIOGRAPHIC REFERENCES}

Adámoli, J., J. Macedo, L.G. Azevedo, and J.M. Neto. 1978. Caracterização da região dos Cerrados. pp. 33-98. In: Giedert, W.J. (ed.) Solos do Cerrado: Tecnologias e estratégias de manejo. CPAC, Planaltina-DF, Brazil.

Aguiar, S., I.S. Santos, N. Arêdes, and S. Silva. 2016. Redes-Bioma: Informação e Comunicação para ação sociopolítica em ecorregiões. Ambient. Soc. 19, 231-248. Doi: 10.1590/1809-4422ASOC20140004V1932016

Alleoni, A.C.C., A.P. Jacomino, and A.S. Rosa. 2006. Recobrimento de Laranja "Pêra" com filme de concentrado proteico de soro de leite associado a plastificantes. Pesq. Agropecu. Bras. 41, 1221-1226. Doi: 10.1590/ S0100-204X2006000800002

Antunes, L.E.C., E.D. Gonçalves, and R. 2006. Trevisan. Alterações de compostos fenólicos e pectina em pós-colheita de frutos de Amora-Preta. Rev. Bras. Agrociênc. 12, 57-61.

AOAC (Association Official Analytical Chemistis). 2010 Official methods of analysis of AOAC International. $18^{\text {th }}$ ed. Gaithersburg, MD, USA.

Assis, O.B.G. and D. Brito. 2014. Revisão: coberturas comestíveis protetoras em frutas: fundamentos e aplicações. Bras. J. Food Technol. 17, 87-97. Doi: 10.1590/ bjft.2014.019

Campos, R.P., B. Knoch, P.A. Hiane, M.I.L. Ramos, and M.M. Ramos Filho. 2011. 1-MCP em Mangabas armazenadas em temperatura ambiente e a $11^{\circ} \mathrm{C}$. Rev. Bras. Frutic. 33, 206-212. Doi:10.1590/S0100-29452011000500024

Calbo, A.G. and A.A. Nery. 1995. Medida de firmeza em hortaliças pela técnica de aplanação. Hortic. Bras. 3, 14-18.

Carnelossi, M.A.G., W.F.F. Toledo, D.C.L. Souza, M.L. Lira, G.F.J. Silva, R. Vahideh Rabani, and P.R.A. Viégas. 2004. Conservação pós-colheita de mangaba (Hancornia speciosa Gomes). Ciênc. Agrotecnol. 28, 1119-1125. Doi: 10.1590/S1413-70542004000500021
Chitarra, M.I.F. and A.B. Chitarra. 2005. Pós-colheita de frutas e hortaliças: fisiologia e manuseio. $2^{\text {nd }}$ ed. UFLA, Lavras-MG, Brazil.

Embrapa. 2007. Sistema de produção da mangaba para os tabuleiros costeiros e baixadas litorâneas. In: http:// sistemasdeproducao.cnptia.embrapa.br/FontesHTML/Mangaba/SistemaProducaoMangabaTabuleirosCosteiros/Introducao.html; consulted: February, 2017.

Fakhouri, F.M. and C. Grosso. 2003. Efeito de Coberturas Comestíveis na vida útil de goiabas in natura (Psidium guajava L.) mantidas sob refrigeração. Bras. J. Food Technol. 6, 203-211.

Farias, J.F., S.E. Araújo Neto, V.S. Álvares, P.A. Ferraz, D.T. Furtado, and M.L. Souza. 2011. Maturação e determinação do ponto de colheita de frutos de enviracaju. Rev. Bras. Frutic. 33, 730-736. Doi: 10.1590/ S0100-29452011005000100

FDA (Food and Drug Administration). 2013. Generally recognized as safe (GRAS). In: http://www.fda.gov/ Food/IngredientsPackagingLabeling/GRAS/; consulted: March, 2017.

Gago, M.B.P., S.M. Serra, and M.A.D. Rio. 2006. Color change of fresh-cut apples coated with whey protein concentrate-based edible coatings. Postharvest Biol. Technol. 39, 84-92. Doi: 10.1016/j.postharvbio.2005.08.002

Lee, S.K. and A.A. Kader. 2000. Preharvest and postharvest factors influencing vitamin $\mathrm{C}$ content of horticultural crops. Postharvest Biol. Tecnol. 20, 207-220.

Nasser, F.A.C.M., A.C. Boliani, M.F. Nasser, and M.K. Pagliarini. 2016. Conservação de mangabas submetidas à aplicação de quitosana. Rev Cientif. 44, 279-295. Doi: 10.15361/1984-5529.2016v44n3p279-285

Strohecker, R. and H.M. Henning. 1976. Análises de vitaminas: métodos comprovados. Ed. Paz Montalvo, Madrid, Spain.

Vicentino, S.L., P.A. Floriano, and D.C. Dragunski. 2011. Filmes de amido de mandioca modificados para recobrimento e conservação de uvas. Quim. Nova 34, 13091314, 2011. Doi: 10.1590/S0100-40422011000800003

Vieira, R.F., T.S. Agostini-Costa, D.B. Silva, S.M. Sano, and F.R. Ferreira. 2010. Frutas nativas da região Centro-Oeste do Brasil. Embrapa Informação Tecnológica, Brasília, Brazil. pp. 188-213. 